\title{
Narratives of innovation that address climate change agenda in the construction sector
}

\author{
Natalya Sergeeva and Carmel Lindkvist
}

The Bartlett School of Construction and Project Management, University College

London, London.

Architecture and Planning Department/ Norwegian University of Science and Technology (NTNU), Norway.

Provide full correspondence details here including e-mail for the corresponding author

Natalya Sergeeva

Affiliation (department and university): The Bartlett School of Construction and Project Management, University College London.

Address: 1-19 Torrington Place, WC1E 7HB, London, UK.

Email: n.sergeeva@ucl.ac.uk

Provide short biographical notes on all contributors here if the journal requires them.

Dr Natalya Sergeeva is an Associate Professor in the Management of Projects at the Bartlett School of Construction \& Project Management, University College London, England. She holds a $\mathrm{PhD}$ degree from the School of Construction Management and Engineering, University of Reading, England. Natalya is actively engaging with professionals in the construction and infrastructure sectors and regularly participates in the networking events. Her research interests include applications of theories such as sensemaking, social identity, narrative and storytelling in understanding innovation in project-based settings. Natalya's work is published in Industrial Marketing Management Journal, International Journal of Project Management, Project Management Journal, International Journal of Innovation Management, European Journal of Innovation Management, Creativity and Innovation Management Journal.

Dr Carmel Lindkvist is an Associate Professor in Facilities Management at the Architecture and Planning, NTNU. She spent eight years working in the UK (University of Reading) and five years working in Norway (NTNU) researching and publishing on facilities management and holistic approaches to sustainable buildings. She draws on organisational management theories to understand the interplay of practices, clients and end users involved in the different stages of a building life-cycle. Her portfolio of research projects includes EU FP7 Near Zero Energy Neighbourhood and London 2012 Olympics and she was co-coordinator in the IEA/SHC Task 51 Solar Energy in Urban Planning. 


\section{Introduction}

This chapter explores narratives of innovation that address the challenges faced in the construction sector and associated firms in meeting the climate change targets. Innovation is important to meet the targets and there is an urgency reflected within continuously developing global strategies and policy initiatives. In this way, innovation must be sustainable with the specific objective to reduce carbon emissions in countries - we refer to this as 'sustainable innovation'. There is a temporal connection within the urgency to set ambitious climate change targets with specific deadlines and the need for industries like the construction sector to act. The UN Framework Convention on Climate Change advocates the necessity for countries to set targets to limit global warming to less than two degrees Celsius above preindustrial temperatures. Countries have set targets to meet emission goals with key years being 2020, 2030 and 2050. At the Paris climate conference (COP21) in December 2015, 195 countries, including Norway and the UK, adopted the first universally, legally binding global climate deal, which comes into effect in 2020. These continuous timelines to meet global/national goals to reduce emissions require support from industries such as the construction sector. The Norway and UK are countries heavily promoting sustainable innovation to meet the construction sector targets set by policy. Since 2010, EU directives have guided the construction sector towards sustainability in Norway and the UK. In this chapter, we focus on this interaction process between climate changing targets at the policy level and the action/reaction of the construction sector firms, both owners/clients and suppliers/main contractors. We also look into the way narratives of innovation are continuously promoted in textual forms in Norway with the focus on working towards (nearly) 'zero emissions' and in the UK with the focus on 'low carbon'. Although maybe labelled differently in each country, we use the term sustainable innovation as most commonly used in both contexts.

This chapter seeks to answer the main question: "How do narratives of innovation that address the climate change agenda in the construction sector in Norway and the UK interact at international, industrial policy and firm levels?" We believe this is an important question to address that has important implications for policy making. The performance of the construction sector rests upon a coalition of leading firms promoting narratives of innovation that address and act on the climate change agenda (Orstavik, Dainty, and Abbott, 2016). These firms and people there within play an important role in 
creating a more systematic and holistic approach to 'low-carbon', 'zero-energy' innovation and changing organisational and industrial culture (Sergeeva, 2016; Winch, 1998). The industrial policy calls for stronger and more systematic links between narratives of sustainable innovation at industrial policy and firm levels (BIS Innovation Infrastructure Project: Working towards and innovation system, 2010; Innovation System, 2017). Yet, little is known about how narratives of sustainable innovation interact: how they pull and push each other to be innovative for sustainable development in approaches and ambitions to reduce carbon emissions. Building upon the "narrative turn' in the organisation studies (Czarniawska, 1997, 2010; Fenton and Langley, 2011; Rhodes and Brown, 2005; Vaara, Sonenshein, and Boje, 2016) and innovation literature (Bartel and Garud, 2009; Garud, Schildt, and Lant, 2014; Reissner, 2005; Seidel and O’Mahony, 2014), we demonstrate the ways textual narratives of sustainable innovation are continuously promoted in construction sector firms that address the targets set by industrial and international levels using specific examples. The narrative turn in innovation studies constitutes a shift in focus away from the material practices of innovation towards understanding how the meaning of innovation is socially constructed using narratives. In this chapter, we refer to the narrative of sustainable innovation as a discourse about the need to change and improve products, processes and services to meet the sustainability targets set by industrial policies and internationally, and to deliver value for customers, which could be environmental, societal, economic etc. To date, there remains little consistency in terms of theoretical approach to narrative interactions in this area and scarce empirical investigation.

Norway intends to reduce energy consumption in general and reduce reliance on fossil fuels. The aim in Norway is to reduce its emissions by at least $40 \%$ by 2030 compared with 1990 levels and be carbon neutral by 2050 through the reduction of domestic greenhouse gas emissions (Alonso and Stene, 2013; EU Emissions Trading System, 2016). Buildings account for about $40 \%$ of energy consumption in Norway, therefore the building industry is an important player when reducing the overall environmental impact of energy use. The Norwegian government strategy document "The Green Shift-climate and environmentally friendly restructuring" refers to policy which has led to stricter buildings regulations on reducing climate gas emissions (Lavenergiprogrammet, 2016). While there is a regulatory process in place leading to standards such as TEK 17 and 
Passive House to reduce carbon emissions, there is no clear analysis on how these processes emerged.

In the UK Construction 2025 strategy sets the target of $50 \%$ reduction in greenhouse gas emissions in the built environment by 2025 and the UK Climate Change Act sets the target to reduce emissions by $80 \%$ by 2050 . The tasks set for companies in the wider construction sector in the UK are: (1) de-carbonise their own business; (2) provide people with buildings that enable them to lead more energy efficient lives; and (3) provide the infrastructure which enables the supply of clean energy and sustainable practices in other areas of the economy (Low carbon construction, 2010).

Whilst there are industrial policy and targets in place to push the Norwegian and the UK construction sector firms to be more innovative and sustainable, it remains unclear how they respond to this push, as well as the interaction between innovation push and pull. This is the knowledge gap that we address in this chapter. In the following sections, we examine the narrative turn in organisation and innovation studies; we present our empirical findings examining push and pull narratives of sustainable innovations between industrial policy and firms in both Norway and UK; and finally, we discuss our conclusion that narrative interactions of sustainable innovation occur at multi levels (international policy, national policy and firm levels).

\section{'Narrative turn' in the organisation studies}

We build upon the 'narrative turn' in organisation studies (Czarniawska, 1997, 2010, 2016; Fenton and Langley, 2011; Rhodes and Brown, 2005; Vaara et al., 2016) to explore the research question about how narratives of sustainable innovation interact policy and firm levels. By a narrative we mean a discursive construction that embodies a degree of coherence, unity of purpose together with connotations of performative intent (Boje, 2001; Cunliffe and Coupland, 2011; Humphreys and Brown, 2002; Sonenshein, 2010). Although rarely fixed or completely monolithic, narratives are nevertheless often repeated in organisations. Indeed, narrative repetition promotes innovation and/or then stabilises particular meanings (Buchanan and Dawson, 2007; Dailey and Browning, 
2014). Narratives hence may carry important messages at the level of the firm and at a sectoral level. Narratives are frequently seen as an integral means of organising (Brown, Stacey, and Nandhakumar, 2008). Organisational narratives tend to become institutionalised in textual forms on websites and firm reports. Industrial policy and international narratives are dominant in legitimising advocated actions by firms and individuals there within (Buchanan and Dawson, 2007).

Practising managers and policy makers play an active role in the construction of such narratives, as they are responsible for formulating and disseminating an organisational vision and strategies (Sims, 2003; Sonenshein, 2010). For example, Abolafia (2010) demonstrates the ways elite policy makers use plotted and plausible narratives to shape the reactions of those in their environment. Top managers sanction organisational values and identity through spoken and written narratives (Bourne and Jenkins, 2013). Sims (2003) further considers the special pressures on managers to tell narratives about their organisations to their superiors and subordinates and in addition, there is an expectation on managers to give coherent narratives of organisational performance to their staff. In this way, narratives play a prominent role in constructing organisational, industrial and national identities.

Time is key in how narratives (re)construct individual and organisational identities (Brown and Thompson, 2013). Dobusch and Schoeneborn (2015) emphasise organisational identity is continually constituted in narrative texts and may be reflexively woven by organisational members. Whilst organisational identity narratives tend to be consistent, they can be modified over time (e.g. strategies are revised; firm reports are rewritten). Narratives hence have important implications for future (re)construction of identities and in the setup of organisational visions and strategies. Narratives of sustainable innovation thus potentially play an important role of establishing an identity and image of 'innovative' and 'sustainable' construction sector. As such, the construction sector firms tend to promote themselves as innovative and sustainable, with these two terms being core organisational values (Opoku, Ahmed, and Cruickshank, 2015). 
Alvesson and Robertson (2015) address identity issues in relation to senior employees in the UK investment-banking sector. Their study demonstrates that senior employees are far less sensitive to identity issues than existing research suggests. Other studies have examined the ways actors have interpreted the past in order to forge organisational identities (Hansen, 2007), and set strategic directions (Schulz and Hernes, 2013). Gioia, Schultz, and Corley (2000, p. 64) argue that organisational identity is commonly understood as an organisational members' collective understanding of the features presumed to be central and relatively permanent, and that distinguish the organisation from other organisations. Expressed values attributes to an organisational identity subject to multiple interpretations by organisational members. Bourne and Jenkins (2013) clarify that top management espouse organisational values through verbal and written statements and formal documents. Organisational values typically refer to the small number of values that are coherent and consistent. Changes in values do occur over time but are typically incremental.

\section{'Narrative turn' in innovation studies}

There is undoubtedly increasing interest amongst scholars of innovation in the importance of narratives (Beckman and Marry, 2009; Reissner, 2005; Seidel and O’Mahony, 2014). Bartel and Garud (2009) distinguish between narratives that portray innovation in a structured way using a plot, and provisional narratives, which capture individual perceptions without any clear plot. The purpose of the former is to promote a coherent viewpoint of innovation, whereas the latter acts as more personalised sense-making mechanisms. Structured narratives of innovation act as "cultural mechanisms for translating ideas across the organisation so that they are comprehensive and appear legitimate to others" (Bartel and Garud, 2009, p. 109). Denning (2005) also sees having the capability to develop narrative tools as essential to the promotion of innovation acting as sense-giving mechanisms. More specifically, narratives of innovation can be seen to carry important messages about organisational vision, directions and strategies (Doganova and Eyquem-Renault, 2009; Fleming, 2001). Garud et al. (2011) further contend that structured narratives provide the organisational memory that enables people to translate emergent ambiguous situations associated with the innovation process into the meaningful present and future. In contrast, provisional narratives enable "real-time problem solving among individuals who must coordinate within and across different 
domains of activity" (Bartel and Garud, 2009, p. 112). This definition points towards a continuous process of social construction through which individuals ascribe meanings to innovation based on their social interactions.

The current literature is largely silent on the way in which innovation narratives interact at cross-levels and the implications of these interactions. Some scholars have taken a micro approach to studying individuals and teams to innovate within their specific contexts (Taylor and Greve, 2006). Others have taken a macro approach offering insights on the role of national, regional and industrial contexts in inducing innovation (Lundvall, 2007). Several multi-level approaches have attempted to bridge the micro-macro boundary (Fenton and Langley, 2011; Vaara et al., 2016), but fall short in addressing the dynamics of this interaction and its implications for actions. This chapter uses insights borrowed from narratology to obtain a better understanding of interactions between narratives of innovation that address the climate change agenda at industrial policy and project-based firm levels. We believe this can offer a greater understanding of what drives innovation across different levels, in terms of the sustainability targets that are set and attempted to be met. It also has important implications for policy making.

\section{The interactions between narratives of sustainable innovation at industrial policy and firm levels}

There is increasing recognition in the literature that the construction sector has progressed in the development of green building practices. Innovation as a process to implement new products, processes and/or management approaches with the intention to improve current practices is a means of achieving more sustainable green practices. At the same time, context plays an important role in understanding innovation (Orstavik et al., 2016). For example, for one firm a practice maybe perceived as new and innovative, but this practice maybe more commonly used elsewhere. Previous research has shown an increased industrial and corporate focus on green innovation that raise the quality of construction projects, sustained and enforced companies' positions in the market, improve collaboration between actors involved (Bossink, 2004). Government regulatory policies play an important role in shaping the direction of innovation and change in the construction industry (Blayse and Manley, 2004; Bossink, 2002). There is also 
consciousness that 'extensive' and prescribed regulations may stifle innovations, as parties have little incentive to improve (Rehan and Nehdi, 2005).

The directives from the EU focus on climate change targets, but it is up to individual countries to decide how these targets are realised. As noted in the construction innovation literature, building policy debates tend to have a narrow focus on value based on economics rather than broader societal or environmental values as well as paying little attention to motivation of the diverse range of stakeholders (Whyte and Sexton, 2011). European policies focus on improving the physical performance of building and market mechanisms (Baek and Park, 2012). Concurrently, policymakers are aware of the importance of non-technical dimensions of organisation, social and behavioural aspects within this area, but these dimensions are relatively under-explored (Schweber and Leiringer, 2012).

Increasingly construction management literature has emphasised how the construction sector's identity is shaped by written narratives of innovation that address sustainability agenda mobilised in government reports, structures and regulations which includes longterm processes (Gluch, 2009). It is clear both industry and policy have narratives of innovation on how they address the climate change agenda, but how they influence each other is not always obvious. Innovation narratives shape how firm and project actors understand an innovation and reconstitute it through their discourses and actions. The project-based nature of construction sector firms reinforces the need for a consistent narrative of sustainable innovation (Hobday, 2000). Due to the project-based and diverse nature of the construction sector, the effective adoption of environmental innovation requires the collaboration of all the parties in the sector (Dewick and Miozzo, 2002). The importance to communicate ideas across the sector is increasingly recognised to broaden adoption of green, sustainable innovations. As Gluch, Gustafsson, and Thuvander (2009, p. 451) state:

"For wider adoption of green innovations and ideas, for example solar panels, low emission glass, passive house design, extended life cycle thinking, and web-based analytical tools, it is important that the 
management group supports and communicates these ideas and innovations so that individuals perceive them as motivating."

We argue that narratives are the ways of communicating 'green' innovations and therein driving it across the sector. Both policy and leading construction firms play an important role in promoting narratives of sustainable innovation and motivating the construction sector to adopt green innovation and develop new solutions.

\section{Methods}

In our empirical investigation, we explore the ways Norwegian and UK construction firms respond to the dominant narrative about the need for sustainable innovation to meet climate change targets set nationally and internationally. The two countries are complementing each other in how they actively promote narratives of sustainable innovation. There are some structural differences such as population size and climate, but we demonstrate the commonality in the ways narratives of sustainability innovation at sector level connect with those at firm levels. The specific steps we followed in our empirical investigation are:

1. Analysis of textual narratives of sustainable innovation identified in the government and industrial policy reports

2. Analysis of textual narratives of sustainable innovation identified in the selected firms' websites

3. Analysis of the narrative interactions in terms of how firms respond to the national and international narratives of sustainable innovation.

In Norway, 18 Norwegian white papers, legislative acts and literary understandings of policy have been analysed to understand the policy perspective of reducing climate change. The white papers and legislative acts are listed in the Appendix (Table 4). This analysis focused primarily on sustainable policy directed at the building industry. In addition, websites of five construction companies leading in innovation of sustainable construction were analysed. These five companies were identified based on their role in pilot and demonstration projects to develop new solutions for the reduction of emissions in buildings. 
In the UK, the textual narratives of innovation which address the low carbon agenda at the policy level are identified and analysed from 15 reports published by government and professional institutions which are publicly available. This is followed by the analysis of narratives of innovation that address low carbon agenda at the firm level through corporate reports and strategies. For consistency purposes, five UK construction firms (both owners and suppliers) are selected which are extensively promoting sustainable innovations through textual narratives evident through firm websites (Table 3 in the Appendix provides more details about the Norwegian and UK companies' backgrounds).

\section{Findings}

\section{Narratives of sustainable innovation in Norway}

\section{Constructing firm identities as leaders of sustainable innovation}

Interaction between policy and industry appears intertwined in the role of transitioning to low emission society on a policy level to already having leaders of low emission building within the building sector. Norwegian policy identifies its roles of sustainability as becoming and transitioning. The "green shift" sums up the need for Norway to change over the next 30 to 50 years. Innovation and technology development are key elements of Norway's green shift to become a low emission society by 2050 (New emission commitment for Norway for 2030, 2014; Innovation Norway: financing of environmental technologies, 2017). While Norway positions itself within the global context, it also positions itself as a country that 'must find its own way'. The Norwegian Government works with UN and the EU to reduce climate emissions and advocates a long-term global objective of approaching net zero emissions by 2050. Norway's intended national determined contribution (INDC) includes the reduction of emissions to at least $40 \%$ by 2030 compared with the 1990 levels. These targets are ambitious and push industries in Norway to think innovatively to address targets. The five companies examined in this study indicate that they are not in transition but primarily identify themselves as 'leaders'. The companies use language of being "first", "leading", being "in front" or aims to be leading. This type of narrative indicates that companies, which are leading, do not need 
to go through the transition process as they are already ahead of other similar industries as illustrated in the quote below.

[Firm B] "is in the front on developing and building future homes which consider energy and environmentally friendly buildings."

The explicit intention illustrated through these narratives is the performative action that the building industry takes the responsibility to reduce carbon emissions seriously and include it as part of their corporate goals. They identify actions of what they do in their firm in sustainable future oriented ways as opposed to the established practices within their field.

Authoritative narrative of advice giving on current standards and regulations

While the building industry narrative does appear to be acting on the call to meet targets, energy performance targets is not a specifically well-established policy field in Norway's building industry (Knudsen \& Dalen, 2014). Priority areas within the climate change agenda are:

- Reduction of emission from the transport sector

- Development of low-emission industrial technology and clean production technology

- Carbon capture and storage

- Strengthening Norway's role as a supplier of renewable energy

- Environmentally-sound shipping (New emission commitment for Norway for 2030 - towards joint fulfilment with the EU, 2014)

However, the building industry is quite active in development of legislation for energy performance of buildings. The technical requirement in buildings, TEK 10 and TEK 17 address energy regulations primarily in new buildings and for very large renovations. The building industry was quite critical of TEK 10 but were active in providing input for TEK 17 (https://dibk.no/byggeregler/tek/). In 2012, the Passive House as a requirement changed to a voluntary initiative due to controversies within the industry (Müller and Berker, 2013), but was changed back to mandatory in 2017. There are two Passive House Standards in Norway - NS3700 for residential and NS3701 for non-residential buildings. The reason for this is that there was controversy on the requirement for energy supply, 
single-family homes and to what extent climate change mitigation should be included. Controversy also emerged due to calculated increased costs of constructing to passive house standard, which hinders market penetration in Norway. However, those supportive of passive house approaches argue that the standard prescribes performance of the dwelling, but leaves open the choice of solutions to achieve the standard. The openness indicates that it is up to industry to find innovative solutions to sustainable building. Therefore, having leaders of sustainable innovation within the construction sector is important to reach passive house standards.

Being in a position of leader and champion of innovation solutions for sustainable construction, enables such companies to form a narrative of authority. This narrative is reflected in the advice-giving services offered to companies who are not leaders of sustainable building practices and who maybe in a position of transitioning. Companies examined in this study can market their position of acting on green innovation to be authoritative figures, not only to policy makers who integrate advice into standards but within their own industry. Therefore, companies who have a leader narrative embedded into a textual form on their website enables also an authoritative narrative to give advice to companies not at the forefront of sustainable building:

"[Firm E] is involved in a number of state and international institutions in connection with product development and certification. The requirements ensure that you as a customer or consumer make the right and proper choice."

Being a leader enables these companies to provide reassurances to potential customers that their experience leads to the "right and proper choices".

\section{Shaping innovation solutions to meet environment and social demands}

Policy initiatives support innovation solutions that Norway's climate change goals through a strong economic narrative. Energiøkonomisering - ENØK is the Norwegian term that encapsulates how energy utilization is directly associated with cost savings, profit or expense (Ryhaug and Sørensen, 2009). National policy instruments do not openly propose innovation but set up economic frames, e.g. funding bodies, in which innovation is attainable. Enova is an important actor in the implementation of new energy 
performance technologies to both private and public sectors. Enova, together with Energy Fund and Innovation Norway offer subsidies and capital loans for development and demonstration of new and existing building projects related to energy reduction, but these loans often come with restrictions that reduces the scope of innovation (https://www.enova.no; http://www.innovasjonnorge.no). There is no clear guidance to industry on how to attain energy targets, but finances are available to reach them. Hence, the narrative of energy economising dominates Norwegian policy.

Policy does not indicate the use of specific energy solutions to building industry, but legislation and regulation nudges the industry towards sustainable solutions. The firm websites in Norway, did not refer to an economic narrative to any great degree. While research studies indicate financial profitability being a factor for developing sustainable solutions (e.g. Lindkvist et al., 2014), companies do not explicitly refer to an economic narrative but focus more on social and environmental narrative. Specifically, in how sustainable solutions can benefit wider environment and social goals:

[Firm A] "The (name) project uses new environmental technologies for renewable energy production in the Norwegian context; this includes a small-scale combined heat and power plant which is based on biomass gasification."

The type of "environmental technologies" mainly refers to renewable energy and energy reduction solutions. Companies also refer to technology in terms of preparing for the future but do so in terms of wider social issues. Firm B refers to developing 'welfare technologies' for 'future new buildings' which enables "elderly and ill can live longer in their own homes" - this may allude to the need for increasing older population to live in their homes longer. Firm D use the green technology narrative as a form of 'defence against air, water and wasted energy' - elements which are impacted by climate change. The economic frames through policy level initiatives in Norway enable financing of social and environment visions within the building industry, primarily done through green technology solutions. 


\section{Beyond ambitions: Technical narrative to innovation}

The level of ambition in sustainable innovation projects is often decided by the technical energy performance of the building. The minimum requirements for industry to meet are set by policy so in this way policy is pulling industry to be sustainable in their building practices. At the same time, these minimum requirements allude to policymakers being heedful towards energy ambitions. Policy does not push the industry to be more ambitious than the minimum standard. However, sustainable innovation in industry influences this technical performance standard as minimum requirements increase as technology facilitates further energy reductions in buildings. These minimum performance standards are in a constant state of flux and requirements have become progressively tougher in line with technology development in sustainable solutions e.g. TEK 10 in 2010 moving to TEK17 in 2017. The link between industry innovation in technology and policy is visible within companies who identify themselves as going beyond present ambitions:

[Firm D's] “Building Envelope offers solutions that meet or exceed codes, help extend building life, and help reduce fossil fuel consumption."

If these companies wish to maintain their leading narrative, thinking in terms of meeting standards is not enough. At the start of a project, there may be an ambition to meet current energy standards but when that project is complete, a more ambitious standard could replace the original standard. Companies who are leading innovators of sustainable construction are prepared to go further to achieve a high ambition as possible.

The analysis outlines the narrative interactions between Norwegian construction sector, (which identifies itself within a green innovation narrative) and emission policy reduction from legislation, and regulations (based on related policy documentation). Table 1 provides an outline of the narrative interactions between documented policy narratives and building industry firm narratives. These narrative interactions are viewed in the way policy setting sustainable targets leads to firms, with expertise to meet these standards, as constructing their identity to be leaders of sustainable innovation. The formalised policy setting targets are developed in regulatory standards facilitating firms who identify themselves within the narrative of sustainable innovation leaders to further this narrative as authoritative and advice giver which they build into their services. The funding available from public bodies builds on the narrative of economizing providing economic 
frames to firms who work within their narrative of shaping innovation solutions to meet environmental and social demands. Finally, policy has a heedful narrative in meeting targets to reduce carbon emissions while firms react within a narrative of either meeting or going beyond ambitions through technical discourse of innovation.

<TABLE 1 HERE>

\section{Narratives of sustainable innovation and their interactions at industrial policy and firm levels in the $U K$}

The interaction between narratives of innovation at industrial policy and firm levels

As outlined earlier in the chapter, sustainable innovation is in the agenda of the UK construction sector. The UK construction sector policy reports set the target for the need for innovations that address 'green', 'sustainable' agenda. There is a strong vision in the UK construction sector as a whole in meeting the sustainability targets for 2030 and 2050. This grand narrative of low-carbon, sustainable innovation at macro-level is highly visible. The analysis of corporate reports and strategies from both owner and supplier UK construction firms demonstrate the alignment with the macro-level narrative of sustainable innovation identified across a number of industry and Government reports. Innovation and sustainability are recognised as key organisational values being represented in the form of firm brochures and symbolically evident in interior designs within selected firms. Some UK construction firms are already recognised as 'sustainable innovation leaders' through industry awards, as illustrated in the below quotation:

"[Firm F] "being praised as 'exceptional progress' on carbon reduction. The firm is already one of the only carbon neutral construction companies and also invests in communities."

There are various industry sustainability awards through which UK construction firms become recognised by others as leaders in sustainable innovation.

A number of UK construction sector firms are in the process of becoming leaders of sustainable innovation:

"[Firm I] "strives to deliver sustainable solutions guided by values. It strives to limit the environmental impact of activities." 
In order to be recognised as sustainable leaders, UK construction firms take into consideration environmental concerns, reduction of carbon emissions, improve efficiency through innovative technologies. These firms also recognise the need to become more sustainable, more innovative sector as a whole.

\section{More specific narratives of sustainable innovations in UK construction firms}

The UK Government and industrial policy not only sets the ambitious targets, but also aims to incentivise the supply chain (e.g. through awards) to come up with and implement sustainable innovation solutions. The UK construction sector firms interact with the narrative of sustainable innovation at the national and industrial policy levels by constructing emergent narratives and act upon them. For example, firm $\mathrm{H}$ focuses on the following key activities:

- Management of environmental impact

- Materials and waste reduction

- Supply chain relationships

- Employee skill-set

- Apprentices

- Engagement with local communities

The sustainability roadmap is used as a guidance which then becomes adjusted to different project types (e.g. highways, local projects, infrastructure, energy and power). Sustainability strategies have become publicly available. These are used for promoting themselves as sustainable leaders among competitors and to gain marker shares. The job roles with 'sustainability' in the titles have emerged in the UK construction sector firms. For instance, firm $\mathrm{G}$ has a long-term ambition to have a positive impact and reduce own emissions as part of their journey. By working in collaboration with other suppliers and clients they help to combat climate change and reduce costs of constructing and operating buildings:

"Our teams assist clients to identify, develop and then achieve their sustainable goals, focusing on issues such as in-use performance and cost-effective outcomes over the lifecycle of the building." 
Firm $\mathrm{G}$ uses digital technologies for construction sites and started calculating and setting targets to reducing wider impact. Among other sustainability activities are employee training and attract new talents in the sector. At the heart of narratives of sustainable innovation of many UK construction firms are health and well-being.

The future-oriented narratives of innovation that address the climate change agenda

The narratives of sustainable innovation clearly connect the past with present and future. There are various ways in which companies promote sustainability and innovation: creating new job roles, formalising sustainability strategy, with an emphasis placed on the innovation. Of particular note is the future aspect of narratives of sustainable innovation. Whilst the UK construction firms self-present themselves as leaders in sustainability and innovation, they aim to become even more sustainable and innovative in the future. They develop the action plans encouraging innovation that delivers sustainable outcomes. For example, firm F developed an action plan to transform the firm to become more sustainable and innovative which includes the following actions:

- Retain carbon standards

- Develop a 'connected' sustainability reporting method to account for the value and impact of our strategy

- Publicly report divisional performance through group review and client workshops

- Collaborate and network across the industry to improve standards

- Develop innovative solutions and bring to the market

- Identify and share learning and best practice internally and across the industry

- Actively work to embed a culture of sustainability in our wider supply chain workforce and our customers, clients, householders and end users

It is evident from the publicly available data (e.g. websites, corporate reports) that UK construction industry firms collaborate and network across owners, suppliers, and users to work together in meeting the policy targets set at a national level. They aim to embed the culture of sustainability across the industry as a whole. 
The analysis outlines the narrative interactions between UK construction sector industrial policy reports in promoting the need for innovation that address environmental issues and how firms respond to the targets set, as presented in Table 2 below. It demonstrates how selected firms respond to the narratives of sustainable innovation identified at the industrial policy levels; and how narratives interact through time and their implications for the future (e.g. strategizing, constructing identities and images, shaping policy agenda).

$<$ TABLE 2 HERE $>$

\section{Discussion}

In this chapter, we found that narratives help to achieve consistency in establishing the alignment of innovation that address the sustainability agenda across industry, firm, and project levels through the connection to national and international policy. In our findings, the meaning of 'sustainable innovation' is constructed based on the interaction between top-down policy approach for the construction sector to react to the climate change agenda and bottom-up in the way leading construction firms push the boundaries of climate change targets. In this way, innovation connectivity is prominent pushing and pulling in both directions between firms and policy levels.

The analysis indicates that there is a connectivity between Norway and the UK in how they understand sustainable innovation within a cross-level approaches from industrial policy and project-based firm narratives. International agendas to reduce carbon emissions are formalised in EU directives and translated into national policy. Our study in Norway and the UK exemplifies the interaction and connectivity between the policy narrative to reduce carbon emissions and the construction sector firms. The sustainable reduction of carbon emissions requires this connectivity at a global, national, industry and firm levels. It is evident from the data that the Government initiatives in Norway and the UK do not go far enough with innovation for sustainability in the construction sector. Yet, it is key to industry players, owners and suppliers, who practice sustainable innovation and our evidence shows that these players are willing to go beyond expectation laid out in policy. These firms respond to the climate change agenda at the industrial 
policy level by formalising their sustainability strategies; using innovative and sustainable technologies; creating new job roles with sustainability and innovation in their titles; creating an environment and culture of sustainability and innovation which is built into their firm's narratives. In Norway, the focus on economy and sustainable innovation is prevalent in policy, which supports the perspective of earlier studies on innovation and policy perspectives (Whyte and Sexton, 2011). Economic frames incorporate financial incentivizes for sustainable innovation on the policy level and underpin these processes in the industry level. At the same time, building firms are pushing their strategy to benefit both the environment and society. In the UK, the construction/infrastructure sector creates an environment to incentivize sustainable innovations with emphasis on environment, society and not just economy. The emphasis is also placed on people's mind-sets, behaviours and culture of being and becoming more innovative and sustainable firms and sector as a whole.

In both Norway and UK, a 'sustainable leader' means connecting other industries to the climate change agenda through an advice-giving narrative. This narrative comes from a perspective of a marketable authority offered in the form of a service. It supports the perspective that green innovation is aiming to increase quality of construction projects and develop collaboration across the sector as described by Bossink (2004). However, this collaboration may not necessarily be equal as distinction arises between leaders and novices. Both narratives from industries in Norway and the UK set themselves up as leaders of sustainable innovation and the narrative in both countries connects to the narrative of policy using text such as 'reduce fossil fuel consumption' or 'zero emission' in Norway and 'carbon reduction' or 'reduce emissions' in the UK. Companies are aware of the need to meet climate change agendas within their own country and relate these agenda to their own narratives on the image of the firm. And it is through a continuous process of narrative interaction that shapes policy making, strategizing, identity and image construction.

Both the Norwegian and the UK Governments have regulatory policies which play an important role in shaping the direction of innovation and change in the construction sector (Blayse and Manley, 2004; Bossink, 2002). At the same time, firms in the UK and Norway also appear to be pushing the boundaries of what is ambitious to reduce target 
emissions set at the national level. This is evident in our data under the narrative to go 'beyond ambitions' either by going beyond current standards in projects as in Norway or by developing strategies that incorporate action plans for 2020 through a future vision as in the UK. Companies who are setting themselves up as leaders of sustainable innovation legitimise themselves through connecting to policy by being authorities on the standards and regulations. They also do this by going beyond legislative requirements (e.g. adopting innovative sustainable technologies and approaches, creating new job roles with innovation and sustainability in their titles). Hence, narratives of innovation that address climate agenda in the construction sectors in Norway and the UK are being underpinned through connectivity to policy narratives.

Figure 1 presents an empirically derived model of interactions between narratives of sustainable innovation at international, industrial policy and firm levels and their implications for practice. Policy is pushing industry to innovate in meeting the international climate change agenda, while project-based firms are incorporating this push as part of innovative product and service solutions (Barrett and Sexton, 2006; Winch, 2005). The figure shows a continuous interaction between narratives of innovation constructed at international and industrial policy level ('innovation push') and how project-based firms respond ('innovation pull') to the narrative at policy level. The innovation push is exemplified by key moments in time such as the UN Framework Convention on Climate Change in 2004 and the Paris Agreement which set international agendas to focus on climate change. In turn, this international agenda pushes national policy to focus on climate change within policy strategic documents, regulation and standards as illustrated in our studies in the UK and Norway. National climate changing strategies are translated into carbon reducing targets initiate an innovation pull in industry and in our study, the building industry to react. This innovation pull does not come at once but evolves over time through reconstructing identities and creating innovative solutions which also influence policy to push industry to innovate further. The continuous process of narrative interactions has important implications for policy making, forming and updating policies and strategies, constructing identities and images.

$<$ FIGURE 1 HERE $>$ 


\section{Conclusions}

This chapter has explored narratives of innovation that address climate change targets set in the construction sector on an international and national levels. Focusing mainly on textual narratives enabled an understanding on how a cross-level approach of innovation from policy and firm is connected. It is evident that narratives of low-carbon, zeroemission innovations have significant rhetorical ground internationally. Government policies, reports and regulations set the targets for low-carbon, energy-efficient industry towards 2020 and 2050. In response, construction sector firms come up with new innovative solutions to address the challenges faced with climate change. The innovation push and pull are in continuous process of interaction that plays an important role in constructing 'green' and 'sustainable' construction sector identity and image. Policy is clearly setting the agenda to push industry to sustainable innovation, but firms go beyond ambitions by pushing policy to be less heedful and more ambitious in the energy reducing targets. This type of interaction means that firms and their representatives need to be involved in the discussion with policy makers on what type of ambitious targets need to be set in the policy documents and agenda. An explicit and interactive connectivity between firms and policy where both continue to push and pull each other but doing so in more open discursive ways (e.g. forums, platforms, conversations). Industry and policy makers should work together to shape and promote sustainable innovation that goes beyond economising but incorporates social aspects and the connectivity of sustainable innovation to the local and global environment.

In this work, we have primarily focused on the link between narrative text in policy documents and industry text from websites and reports. However, further work is needed to look at best practice projects in how the narrative work amongst different building practices and construction projects. There is scope to go further with research into symbolic and spoken narratives of sustainable innovation represented in visual data, videos and conversation/interviews. Narratives of low-carbon, zero-energy innovations serve for purpose of everybody being aware of the sustainability agenda and the need to adapt to changes in the climate. Examining innovation connectivity through narratives plays an important role in setting visions and strategies for the direction the construction sector is going to take in the future. 


\section{References}

Abolafia, M.Y. (2010) 'Narrative construction as sensemaking: How a central bank thinks', Organization Studies, volume 31(3), pp. 349-367.

Alonso, M.J. and Stene, J. (2013) State of the Art of Nearly Zero Energy Buildings Country Report IEA HPP Annex 40 Task 1-Norway International Energy Agency/ Heat Pump Programme.

Alvesson, M. and Robertson, M. (2015) 'Money matters: Teflonic identity manoeuvring in the investment banking sector' Organization Studies, volume 37(1), pp.7-34.

Baek, C.H. and Park, S.H. (2012) 'Policy measures to overcome barriers to energy renovation of existing buildings' Renewable and Sustainable Energy Reviews, volume 16, pp. 3239-3947.

Barrett, P. and Sexton, M. (2006) 'Innovation in small, project-based construction firms' British Journal of Management, volume 17(4), pp. 331-346.

Bartel, C. A. and Garud, R. (2009) 'The role of narratives in sustaining organizational innovation' Organization Science, volume 20(1), pp. 107-117.

Beckman, S. and Marry, M. (2009) 'Design and innovation through storytelling. International Journal of Innovation Science, volume 1 (4), pp. 151-160.

Blayse, A.M. and Manley, K. (2004) 'Key influences on construction innovation' Construction Innovation, volume 4(3), pp.143-154.

Boje, D.M. (2001) Narrative methods for organizational and communication research. London: Sage Publications.

Bossink, B. A. G. (2002) 'A Dutch public-private strategy for innovation in sustainable construction' Construction Management and Economics, volume 20(7), pp.633642.

Bossink, B.A.G. (2004) 'Managing drivers of innovation in construction networks' Journal of Construction Engineering and Management, volume 130(3), pp.337345.

Bourne, H. and Jenkins, M. (2013) 'Organizational values: A dynamic perspective'. Organization Studies, volume 34(4), pp. 495-514. 
Brady, T., \& Davies, A. (2004) 'Building project capabilities: From exploratory to exploitative learning in organization studies', Organisation Studies, 25(9), pp.16011621.

Brown, A.D. and Humphreys, M. (2003) 'Epic and tragic tales: Making sense of change', Journal of Applied Behavioural Science, volume 39(2), pp. 121-144.

Brown, A. D. and Thompson, E. R. (2013) 'A narrative approach to strategy-as-practice', Business History, volume 55(7), pp.1143-1167.

Brown, A.D., Stacey, P. and Nandhakumar, J. (2008) 'Making sense of sensemaking narratives', Human Relations, volume 61(8), pp. 1035-1062.

Buchanan, D. and Dawson, P. (2007) 'Discourse and audience: organizational change as multi-story process', Journal of Management Studies, volume 44(5), pp. 669-686.

Building our Industrial Strategy: Green Paper (2017). London: HM Government.

Construction 2025: Industrial strategy: Government and industry in partnership (2013). HM Government, London, UK.

Cunliffe, A. and Coupland, C. (2011) 'From hero to villain to hero: Making experience sensible through embodies narrative sensemaking', Human Relations, volume 65(1), pp. 63-88.

Czarniawska, B. (1997) A narrative approach to organization studies. London: Sage Publications.

Czarniawska, B. (2010) 'The uses of narratology in social and political studies', Critical Policy Studies, volume 4(1), pp.58-76.

Czarniawska, B. (2016) 'Performativity of social sciences as seen by organization scholar', European Management Journal, volume 34(4), pp. 315-318.

Dailey, S.L. and Browning, L. (2014) 'Retelling stories in organizations: Understanding the functions of narrative repetition', Academy of Management Review, volume 39(1), pp. 22-43.

Dewick, P., and Miozzo, M. (2002) 'Sustainable technologies and the innovationregulation paradox', Futures, volume 34 (9-10), pp. 823-840.

Denning, S. (2005) 'Transformational innovation: A journey by narrative' Strategy \& Leadership, volume 33(3), pp. 11-16. 
Dewick, P. and Miozzo, M. (2002) 'Sustainable technologies and the innovationregulation paradox' Futures, volume 34(9-10), pp. 823-840.

Dobusch, L., and Schoeneborn, D. (2015) 'Fluidity, identity, and organizationality: The communicative constitution of anonymous', Journal of Management Studies, volume 52(8), pp.1005-1035.

Doganova, L. and Eyquem-Renault, M. (2009) 'What do business models do? Innovation devices in technology entrepreneurship', Research Policy, volume 38(10), pp. 1559-1570.

EU Emissions Trading System (2016). https://ec.europa.eu/clima/sites/clima/files/factsheet_ets_en.pdf. (Accessed 3 May 2017).

Fenton, C. and Langley, A. (2011) 'Strategy as practice and the narrative turn', Organization Studies, volume 32(9), pp. 1171-1196.

Garud, R., Dunbar, R. L. M., \& Bartel, C. A. (2011) 'Dealing with unusual experiences: A narrative perspective on organizational learning', Organization Science, volume 22(3), pp. 587-601.

Garud, R., Schildt, H.A., and Lant, T.K. (2014) 'Entrepreneurial storytelling, future expectations, and the paradox of legitimacy', Organization Science, volume 25(5), pp. 1479-1492.

Gioia, D. A., Schultz, M., and Corley, K. G. (2000) 'Organizational identity, image, and adaptive instability', Academy of Management Review, volume 25(1), pp. 63-81.

Gluch, P. (2009) 'Unfolding roles and identities of professionals in construction projects: Exploring the informality of practices', Construction Management and Economics, volume 27(10), pp. 959-968.

Gluch, P., Gustafsson, M., and Thuvander, L. (2009) 'An absorptive capacity model for green innovation and performance in the construction industry', Construction Management and Economics, volume 27(5), pp. 451-464.

Hobday, M. (2000) 'The project-based organisation: An ideal form for management of complex products and systems?' Research Policy, volume 29(7/8), pp. 871-893. 
Humphreys, M. and Brown, A.D. (2002) 'Narratives of organizational identity and identification: A case of hegemony and resistance', Organization Studies, volume 23(3), pp. 421-447.

Hansen, P.H. (2007) 'Organizational culture and organizational change: A narrative analysis of the transformation of savings banks in Denmark, 1965-1990', Enterprise \& Society, volume 8(4), pp. 920-953.

Hansen, P.H. (2012) 'Business history: A cultural and narrative approach', Business History Review, volume 86(4), pp. 693-717.

Innovation system (2017). London, UK: Nesta.

Innovation Norway: financing of environmental technologies http://www.innovasjonnorge.no/no/finansiering/miljoteknologi/. (Accessed 1 March 2017)

International Energy Agency (2013) 'Redrawing the World Energy-Climate Map' in World Energy Outlook Special Report. International Energy Agency

Knudsen, J.K. and Dalen, K. (2014) 'Policy framework for the interaction between buildings and the energy system' in Norway. Report WP4 INTERACT.

Lavenergiprogrammet Hva er et passivhus? http://www.lavenergiprogrammet.no/artikkel/hva-er-et-passivhus/ (Accessed 1 February 2016).

Low carbon construction: Innovation \& growth team (2010) HM Government, London, UK.

Lindkvist, C., Karlsson, A., Sørnes, K., and Wyckmans, A. (2014) 'Barriers and challenges in nZEB Project in Sweden and Norway', Energy Procedia, volume 58, pp. 199-206.

Lundvall, B.-A. (2007) 'National innovation systems - analytical concept and development tool', Industry and Innovation, volume 14 (1), 95-119.

Maclean, M., Harvey, C., and Chia, R. (2011) 'Sensemaking, storytelling and the legitimization of elite business careers' Human Relations, volume 65(1), pp.17-40. 
Müller, L. and Berker, T. (2013) 'Passive House at the crossroads: The past and the present of voluntary standard that managed to bridge the energy efficiency gap', Energy Policy, volume 60, pp. 586-593.

New emission commitment for Norway for 2030 - towards joint fulfilment with the EU (2014). Norway: Norwegian Ministry of Climate and Environment.

Opoku, A., Ahmed, V. and Cruickshank, H. (2015) 'Leadership style of sustainability professionals in the UK construction industry', Built Environment Project and Asset Management, volume 5(3), pp. 184-201.

Orstavik, F., Dainty, A. and Abbott, C. (2015) Construction innovation. Chichester, UK: John Wiley \& Sons.

Quasthoff, U.M. (2013) 'Positioning as membership management: The case of narratives about public authorities', Narrative Inquiry, volume 23(1), pp. 132-153.

Rehan, R., and Nehdi, M. (2005) 'Carbon dioxide emission and climate change: policy implications for the cement industry', Environmental Science \& Policy, volume 8(2), pp. 105-114.

Reissner, S.C. (2005). 'Learning and innovation: A narrative analysis', Journal of Organizational Change Management, volume 18(5), pp. 482-494.

Rhodes, C. and Brown, A. D. (2005) 'Narrative, organizations and research', International Journal of Management Reviews, volume 7(3), pp.167188.

Ryhaug, M. and Sørensen, K. H. (2009) 'How energy efficiency fails in the building industry', Energy Policy, volume 37, pp. 984-991

Schultz, M. and Hernes, T. (2013) 'A temporal perspective on organizational identity' Organization Science, volume 24(1), pp. 1-21.

Schweber, L. and Leiringer, R. (2012) 'Beyond the technical: a snapshot of energy and buildings research', Building Research \& Information, volume 40 (4), pp. 481-492

Seidel, V. P. and O'Mahony, S. (2014) 'Managing the repertoire: Stories, metaphors, prototypes and concept coherence in product innovation', Organization Science, volume 25(3), pp. 691-712. 
Sergeeva, N. (2016) 'What makes an 'innovation champion'?', European Journal of Innovation Management, volume 19(1), pp. 72-89.

Sims, D. (2003) 'Between the millstones: A narrative account of the vulnerability of middle managers' storying', Human Relations, volume 56(10), pp. 1195-1211.

Sonenshein, S. (2010) 'We're changing - Or are we? Untangling the role of progressive, regressive, and stability narratives during strategic change implementation', Academy Management Journal, volume 53(3), pp. 477-512.

Taylor, A. and Greve, H. R. (2006) 'Superman or the fantastic four? Knowledge combination and experience in innovative teams', Academy of Management Journal, volume 49(4), pp.723-740.

Winch, G. M. (1998) 'Zephyrs of creative destruction: Understanding the management of innovation in construction', Building Research \& Information, volume26(4), pp. 268-279.

Winch, G. M. (2005) 'Managing complex connective processes - innovation brokering' in A. Manseau and R. Shields (eds.). Building tomorrow: Innovation in construction and engineering. London, UK: Ashgate, pp. 81-101.

Whyte, J. and Sexton, M. (2011). 'Motivations for innovation in the built environment: New direction for research', Building Research and Information, volume 39(5), pp.473-482.

Vaara, E., Sonenshein, S. and Boje, D. (2016) 'Sources of stability and change in organizations: Approaches and directions for future research', The Academy of Management Annals, volume 10(1), pp.495-560.

\section{Acknowledgement}

The authors would like to extend our gratitude to the editors of this book Malena Ingemansson Havenvid, Åse Linné, Lena Bygballe and Chris Harty for their comments, early comments from Finn Ørstavik and input from participants of the ENRIC workshops. We would like to thank FP7 ZenN grant agreement no 314363, which partially funded data collection in Norway as well as Taru Uusinoka for assistance in gathering Norwegian policy documents. 


\section{Appendix}

<TABLE 3 HERE>

$<$ TABLE 4 HERE > 